\title{
Registered report: The CD47-signal regulated protein alpha (SIRPa) interaction is a therapeutic target for human solid tumors
}

\author{
Denise Chroscinski ${ }^{1}$, Nimet Maherali², Erin Griner ${ }^{3}$, Reproducibility Project: \\ Cancer Biology*†
}

${ }^{1}$ Noble Life Sciences, Gaithersburg, Maryland, United States; ${ }^{2}$ Harvard Stem Cell Institute, Cambridge, Massachusetts, United States; ${ }^{3}$ University of Virginia, Charlottesville, United States

\section{REPRODUCIBILITY CAROJECT} CANCER BIOLOGY

*For correspondence: tim@cos.io

Group author details

${ }^{\dagger}$ Reproducibility Project:

Cancer Biology

See page 8

Competing interests: See page 8

Funding: See page 8

Received: 03 September 2014 Accepted: 20 December 2014

Published: 26 January 2015

Reviewing editor: Joan Massagué, Memorial SloanKettering Cancer Center, United States

(c) Copyright Chroscinski et al. This article is distributed under the terms of the Creative Commons Attribution License, which permits unrestricted use and redistribution provided that the original author and source are credited.
Abstract The Reproducibility Project: Cancer Biology seeks to address growing concerns about reproducibility in scientific research by conducting replications of 50 papers in the field of cancer biology published between 2010 and 2012. This Registered report describes the proposed replication plan of key experiments from 'The CD47-signal regulatory protein alpha (SIRPa) interaction is a therapeutic target for human solid tumors' by Willingham et al., 2012, published in PNAS in 2012. The key experiments being replicated are those reported in Figure 6A-C and Table S4. In these experiments, Willingham et al., 2012 test the safety and efficacy of anti-CD47 antibody treatment in immune competent mice utilizing a syngeneic model of mammary tumor growth in FVB mice. The Reproducibility Project: Cancer Biology is a collaboration between the Center for Open Science and Science Exchange, and the results of the replications will be published in eLife.

DOI: 10.7554/eLife.04586.001

\section{Introduction}

Phagocytosis is an essential process utilized by an organism for pathogen or apoptotic cell clearance (Poon et al., 2014). CD47 is a cell surface glycoprotein with a variety of functions including regulation of phagocytosis through binding to the macrophage and dendritic cell specific protein signal regulatory protein alpha (SIRPa) (Oldenborg, 2013). Binding of SIRPa to CD47 essentially sends a 'don't eat me' message to macrophages by initiating signaling to inhibit phagocytosis (Murata et al., 2014).

Increased expression of CD47 is proposed to be a mechanism through which cancer cells evade immune detection and phagocytosis. CD47 expression is increased in several cancer types including acute myeloid leukemia (AML), acute lymphoblastic leukemia (ALL), non-Hodgkin lymphoma (NHL), primary effusion lymphoma, multiple myeloma, leiomyosarcoma, and bladder cancer, and targeting of CD47 on cancer cells with an anti-CD47 blocking antibody can promote phagocytosis by macrophages in vitro (Chan et al., 2009; Jaiswal et al., 2009; Majeti et al., 2009; Chao et al., 2010a; Edris et al., 2012). Further, treatment with an anti-CD47 blocking antibody synergized with rituximab treatment to promote phagocytosis in vitro and to eliminate cancer cells in an in vivo xenograft model of nonHodgkin lymphoma (Chao et al., 2010b). This is supported in two syngeneic murine tumor models, in melanoma and squamous cell carcinoma, where irradiation combined with antisense suppression of CD47 delayed tumor growth (Maxhimer et al., 2009). Willingham et al., 2012 further extend these results to demonstrate that CD47 expression increases in a variety of human solid tumor types and that blocking the SIRPa/CD47 interaction with an anti-CD47 antibody can promote phagocytosis of solid tumor cells in vitro and reduce growth of solid tumors in vivo. While it is not clear if SIRPa signaling is 
involved in the antitumor activity of an anti-CD47 antibody, these results indicate that anti-CD47 antibody therapy may be an effective treatment for a variety of solid tumor types (Soto-Pantoja et al., 2012).

In Figures 6B, 6C, and Table S4, the safety and efficacy of anti-CD47 antibody treatment are tested in immune competent mice using a syngeneic breast cancer model. MT1A2 mouse mammary cancer cells were implanted in the mammary fat pads of FVB mice and IgG control or anti-CD47 antibody treatment commenced upon detection of palpable tumors. Tumor growth was measured by gross weight and analyzed by immunohistochemistry. Willingham et al., 2012 showed that anti-CD47 antibody treatment reduced tumor growth and increased lymphocytic infiltration to the tumor site without unacceptable toxicity, thus demonstrating that anti-CD47 therapy is effective in reducing solid tumor growth in immune competent hosts. This key experiment demonstrates that CD47 is a therapeutic target for solid tumors and follows similar reports from the same laboratory that also demonstrated that anti-CD47 antibody treatment reduced growth of primary human cancer xenografts of several hematopoietic cancers and of solid leiomyosarcoma tumors (Jaiswal et al., 2009; Majeti et al., 2009; Chao et al., 2010a; Edris et al., 2012). Subsequent reports extended these results to multiple myeloma and primary effusion lymphoma models (Kim et al., 2012; Goto et al., 2014). These experiments will be replicated in Protocol 1.

\section{Materials and methods}

\section{Protocol 1: Engraftment of mouse breast cancer cells and treatment with targeted antibodies}

This experiment tests the safety and efficacy of anti-CD47 antibody treatment in immune competent mice using a syngeneic model of mammary cancer. This experiment replicates figures $6 \mathrm{~B}, 6 \mathrm{C}$, and table S4 of the original article, which assess tumor growth by weight of the tumor 30 days after implantation, lymphocytic infiltration by immunohistochemistry, and toxicity by blood analysis.

\section{Sampling}

1. Experiment has 2 cohorts:

A. MT1A2 allograft treated with lgG isotype control.

B. MT1A2 allograft treated with anti-CD47 clone MIAP410.

2. Experiment will use seven mice per treatment group.

A. To account for unexpected deaths, seven mice will be used per group to ensure at least five will survive for a minimum power of $80 \%$.

B. A separate, untreated cohort of three mice will be used to gather baseline readings for the blood analysis.

I. See 'Power calculations' section for details.

\section{Materials and reagents}

All known differences are indicated by an asterisk, with the originally used item listed in the comments section.

\begin{tabular}{|c|c|c|c|c|}
\hline Reagent & Type & Manufacturer & Catalog \# & Comments \\
\hline MT1A2 & Cell line & Original lab & $\mathrm{n} / \mathrm{a}$ & From original lab \\
\hline $\begin{array}{l}\text { Dulbecco's Modified Eagle's } \\
\text { Medium, high glucose with } \\
\text { HEPES modification }\end{array}$ & Cell culture & Sigma-Aldrich & D6171 & \multirow{2}{*}{$\begin{array}{l}\text { Included during } \\
\text { communication with } \\
\text { original authors. Original } \\
\text { lab used Gibco } \\
\text { catalog \# 12430-054 }\end{array}$} \\
\hline L-glutamine & Cell culture & Sigma-Aldrich & G7513 & \\
\hline Fetal bovine serum & Cell culture & Sigma-Aldrich & F0392 & \\
\hline Penicillin/Streptomycin (100x) & Cell culture & Sigma-Aldrich & P433 & \\
\hline
\end{tabular}

Table 1. Continued on next page 
Table 1. Continued

\begin{tabular}{|c|c|c|c|c|}
\hline Reagent & Type & Manufacturer & Catalog \# & Comments \\
\hline Trypsin-EDTA & Cell culture & Sigma-Aldrich & T3924 & \\
\hline $\begin{array}{l}\text { Hank's balanced salt } \\
\text { solution }\end{array}$ & Cell culture & Sigma-Aldrich & $\mathrm{H} 6648$ & \\
\hline T75 flask & Labware & Sigma-Aldrich & Z707503 & \\
\hline 50-ml tubes & Labware & Sigma-Aldrich & CLS430290 & \\
\hline $1 \mathrm{M}$ Hepes in normal saline & Buffer & Biowhittaker & 17-737E & $\begin{array}{l}\text { Included during } \\
\text { communication with original } \\
\text { authors }\end{array}$ \\
\hline BSA, lgG free & Chemical & $\begin{array}{l}\text { Jackson } \\
\text { Immunoresearch }\end{array}$ & $001-000-161$ & $\begin{array}{l}\text { Included during } \\
\text { communication with original } \\
\text { authors. }\end{array}$ \\
\hline Kolliphor P188 & Chemical & Sigma-Aldrich & K4894 & $\begin{array}{l}\text { Included during } \\
\text { communication with } \\
\text { original authors. Original } \\
\text { lab used Pluronic F-68 } \\
\text { which has been } \\
\text { discontinued }\end{array}$ \\
\hline $\begin{array}{l}\text { Leibovitz L15 media, no } \\
\text { phenol red }\end{array}$ & Cell culture & Life Technologies & 21083027 & $\begin{array}{l}\text { Included during } \\
\text { communication with original } \\
\text { authors }\end{array}$ \\
\hline $\begin{array}{l}\text { Matrigel Matrix High } \\
\text { Concentration* }\end{array}$ & Cell culture & Corning & 354248 & $\begin{array}{l}\text { Original from Becton } \\
\text { Dickinson }\end{array}$ \\
\hline $\begin{array}{l}\text { 6-8 week old female } \\
\text { FVB mice }\end{array}$ & Animal model & Charles River & $\begin{array}{l}\text { Strain Code: } \\
207\end{array}$ & Original from Jackson Labs \\
\hline $271 / 2 \mathrm{G}$ needle & Labware & Sigma-Aldrich & Z192384 & $\begin{array}{l}\text { Included during } \\
\text { communication with original } \\
\text { authors }\end{array}$ \\
\hline 1-ml syringe & Labware & Sigma-Aldrich & Z192090 & \\
\hline $301 / 2 \mathrm{G}$ needle & Labware & Sigma-Aldrich & Z192341 & $\begin{array}{l}\text { Included during } \\
\text { communication with original } \\
\text { authors. Original lab used } \\
31 \text { gauge }\end{array}$ \\
\hline $1-5 \%$ isoflurane & Chemical & $\begin{array}{l}\text { Specific brand inform } \\
\text { replicating lab and re }\end{array}$ & $\begin{array}{l}\text { ation will be le } \\
\text { corded later }\end{array}$ & t up to the discretion of the \\
\hline Anti-CD47 clone MIAP410 & Antibody & Original lab & $\mathrm{n} / \mathrm{a}$ & From original lab \\
\hline Mouse IgG isotype control & Antibody & Innovative Research & IR-MS-GF & \\
\hline PBS & Buffer & Sigma-Aldrich & D8537 & \\
\hline Hematology analyzer* & Instrument & Idexx Laboratories & ProCyte Dx & $\begin{array}{l}\text { Original lab used a Heska } \\
\text { HemaTrue }\end{array}$ \\
\hline Neutral buffered formalin & Buffer & \multirow{7}{*}{\multicolumn{3}{|c|}{$\begin{array}{l}\text { Specific brand information will be left up to the discretion of the } \\
\text { replicating lab and recorded later }\end{array}$}} \\
\hline Ethanol & Chemical & & & \\
\hline Xylene & Chemical & & & \\
\hline Paraffin & Chemical & & & \\
\hline Carazzi's Hematoxylin & Stain & & & \\
\hline Eosin & Stain & & & \\
\hline Permount & Chemical & & & \\
\hline
\end{tabular}

\section{Procedure}

\section{Notes}

A. All cells will be sent for mycoplasma testing and STR profiling.

B. Cells maintained in DMEM supplemented with $4 \mathrm{mM} \mathrm{L-glutamine,} \mathrm{10 \%} \mathrm{FBS,} 100 \mathrm{U} / \mathrm{ml}$ penicillin and $100 \mu \mathrm{g} / \mathrm{ml}$ streptomycin at $37^{\circ} \mathrm{C}$ in a humidified atmosphere at $5 \% \mathrm{CO}_{2}$. 
1. Culture MT1A2 cells, count cells, gently spin down, and resuspend in FACS buffer so that 50,000 cells can be injected per mouse.

A. Prepare cells in FACS buffer at 50,000 cells $/ 75 \mu$ l.

B. FACS buffer $(500 \mathrm{ml})$ :

i. $5 \mathrm{ml} 1 \mathrm{M}$ Hepes, $\mathrm{pH}=7.4$.

ii. $500 \mathrm{mg} \mathrm{BSA}$, IgG free.

iii. $680 \mathrm{mg}$ Kolliphor P188.

iv. $5 \mathrm{ml} \mathrm{100X} \mathrm{Pen/strep.}$

v. Bring up to $500 \mathrm{ml}$ with Leibovitz L15 media, no phenol red.

2. Add high protein matrigel to obtain $25 \% \mathrm{vol} / \mathrm{vol}$ solution.

A. Total volume/injection is $100 \mu \mathrm{l}$ and 50,000 cells.

3. Inject 50,000 cells into the left abdominal mammary fat pad (\#4) of 6 to 8-week-old female FVB mice using a $271 / 2 \mathrm{G}$ needle.

A. Use $1-5 \%$ isoflurane at $1-2 \mathrm{l} / \mathrm{min}$ to anesthetize the mice.

B. Total number of mice injected is 14 .

4. Check mice until palpable tumors form in at least 12 animals.

A. Approximately 7-10 days after injection palpable tumors will arise.

5. Randomize mice with palpable tumors to two treatment groups using the following method.

A. On the day the mice are randomized, measure tumors. Animals with no detectable tumors are excluded from the study.

B. Animals are ranked according to tumor size, to balance groups for baseline tumor characteristics, and assigned to group 1 or group 2 using an alternating serpentine method. (rank $1=$ group 1 , rank 2 = group 2 , rank 3 = group 1 , rank 4 = group 2 , etc).

i. Designation of IgG or CD47 antibody treatment as group 1 or group 2 determined by randomly assigning the two treatments into one block using www.randomization.com. Record seed number.

6. Inject $400 \mu \mathrm{g}$ of antibody, administered in $100 \mu \mathrm{l} \mathrm{PBS}$, into mammary fat pad proximal to tumor with an approximate distance of $2 \mathrm{~mm}$ to the tumor (do not inject directly into tumor), every other day for 30 days using a $30 \mathrm{G}$ needle.

C. anti-CD47 clone MIAP410 (mouse lgG1).

D. mouse $\lg G$ isotype control.

7. 5 days after the beginning of antibody injections perform complete blood cell counts to assess treatment toxicity with hematology analyzer.

A. Collect $0.2 \mathrm{ml}$ blood by retro-orbital bleeding.

B. Collect $0.2 \mathrm{ml}$ blood from three untreated female FVB mice to gather a baseline reading.

8. After 30 days of antibody treatment, sacrifice mice, dissect, and weigh tumor.

9. Dissected tumors are processed for further analysis.

A. Immediately, place tissues into $10 \%$ neutral buffered formalin overnight at room temperature.

B. Dehydrate tissues through graded alcohols $(50 \%, 70 \%, 95 \%$ ethanol) and clear xylene.

C. Infiltrate with paraffin, and then embed tissues in a paraffin block.

D. Cut paraffin blocks on a microtome with a section thickness of $5 \mu \mathrm{m}$.

10. Stain tumor sections with H\&E (total: 2 stained sections per tumor).

A. Deparaffinize sections 2 times in xylene, then rehydrate through graded alcohols $(95 \%, 70 \%$, $50 \%$ ethanol) to water.

B. Stain sections with Carazzi's hematoxylin, then rinse slides in water. 

C. Stain sections with eosin.
D. Dehydrate sections through graded alcohols (50\%, 70\%, 95\% ethanol) and then place in xylene.
E. Apply coverslips to slides with Permount and store slides at room temperature.

11. Blindly image stained sections and have images blindly analyzed by a Board Certified Pathologist to analyze lymphocytic infiltration of the tissue sections.

A. Assess absence or presence of tumor infiltrating lymphocytes in at least 10 random fields at high power magnification $(\times 400)$ and score lymphocytic infiltration using the following system (Demaria et al., 2001):
i. 0 = absent.
ii. $1=$ minimal.
iii. 2 = moderate.
iv. 3 = brisk.

\section{Deliverables}

1. Data to be collected:

A. Mouse health records: general health, weight, and age at time of transplant, survival.

B. Lab records on time course of tumor formation (noting when tumors become palpable), transplants, and antibody injections (including seed number of randomization).

C. Image of each tumor at harvest.

D. Raw numbers and graph of tumor weight in control and anti-CD47-treated mice (compare to Figure 6B).

E. H\&E stained sections from each tumor analyzed (compare to Figure 6C).

F. Pathology report for each section and tumor analyzed.

G. Complete blood cell counts in control and anti-CD47-treated mice.

\section{Confirmatory analysis plan}

This experiment assesses if treatment with an anti-CD47 therapeutic antibody alters breast tumor growth in immune competent hosts and examines the safety of the treatment by looking at blood toxicity. The histological analysis of lymphocytic infiltration of the tumors will be reported for each tumor generated during the study, along with the H\&E stained sections. This replication attempt will perform the following statistical analysis.

\section{A. Statistical analysis:}

Note: At the time of analysis we will perform the Shapiro-Wilk test and generate a quantilequantile plot to assess the normality of the data. We will also perform Levene's test to assess homoscedasticity. If the data appear skewed, we will perform an appropriate transformation in order to proceed with the proposed statistical analysis. If this is not possible, we will perform the equivalent non-parametric test.

1. Tumor weight from isotype control treated mice to anti-CD47 clone MIAP410 treated mice.

i. Unpaired two-tailed Welch's t-test.

B. Hematological parameters (13 parameters) tested in untreated mice, lgG isotype control treated mice, and anti-CD47 clone MIAP410 treated mice.

1. Two-way ANOVA ( $3 \times 13$ design) with the following planned comparisons with the Bonferroni correction:

i. One-way ANOVA of untreated, IgG, and anti-CD47-treated mice for each hematological parameter.

ii. Compare the effect size of the original data to the replication data and use a meta-analytic approach to combine the original and replication effects, which will be presented as a forest plot. 


\section{Known differences from the original study}

The replication attempt will not include the anti-CD47 clone MIAP301. The replication attempt will analyze lymphocytic infiltration of the tumors using a scoring system of the H\&E stained sections, which was not implemented by the original study, and is included as exploratory analysis. Toxicity will be assessed during the course of the efficacy experiment instead of on a different strain and cohort of mice as the original study, which was determined in BALB/c mice. Additionally, the replication study will analyze blood 5 days after the beginning of antibody treatment, which precedes a total of three antibody treatments at a dose of $400 \mu \mathrm{g} /$ injection. This is similar to the original study, which analyzed blood 5 days after two successive daily antibody injections of $500 \mu \mathrm{g} /$ injection. To determine the baseline reading, untreated female FVB mice will be also be analyzed. The Idexx Laboratories ProCyte Dx hematology analyzer will assess the same parameters as the Heska HemaTrue used in the original study. All known differences of materials and reagents are listed in the 'Materials and reagents' section above, indicated by an asterisk, with the originally used item listed in the comments section. All differences have the same capabilities as the original and are not expected to alter the experimental design.

The original study analyzed the data using a Student's $t$-test, however since the original data variance is not homogenous the Welch's t-test for comparing the samples will be used instead.

\section{Provisions for quality control}

The cell line used in this experiment will undergo STR profiling to confirm its identity and will be sent for mycoplasma testing to ensure there is no contamination, as well as rodent pathogen screening to ensure there are no detectable pathogens. The anti-CD47 clone MIAP410 will be checked to verify the specificity by ELISA, which is being conducted by the original lab. The retro-orbital bleeds will be performed by a Science Exchange lab with expertise in this technique to minimize stress. Subjective data collection will be performed blinded to the experimental conditions and treatment groups will be assigned in a random manner with the seed number recorded to reproduce the plan. All of the raw data, including the H\&E stained sections, will be uploaded to the project page on the OSF (https://osf. io/9pbos) and made publically available.

\section{Power calculations}

Protocol 1

Summary of original data (provided by original authors).

\begin{tabular}{llll} 
Dataset being analyzed & N & Mean & SD \\
\hline Tumor weight of IgG-treated mice & 5 & 0.1445 & 0.05203 \\
\hline Tumor weight of anti-CD47 clone MIAP410 treated mice & 5 & 0.01224 & 0.002258
\end{tabular}

\section{Test family}

A. 2 tailed Welch's $t$ test, difference between two independent means, alpha error $=0.05$.
Power calculations (performed with R software, version 3.1.2) (R Core Team, 2014).

\begin{tabular}{llllll} 
& & & & Group 1 & Group 2 \\
Group 1 & Group 2 & Effect size (Glass' $\Delta)^{*}$ & A priori power & $\begin{array}{l}\text { sample size } \\
\text { sample size }\end{array}$ \\
\hline IgG & MIAP410 & 2.541995 & $99.8 \%$ & 5 & 5
\end{tabular}

*The IgG control group SD was used as the divisor.

Summary analysis of original data presented in Table S4 (Willingham et al., 2012):

Test family

A. 2-way ANOVA (3 treatments x 13 hematology parameters), Fixed effects, special, main effects, and interactions, alpha error of 0.05 . 
i. ANOVA analysis performed with R software, version 3.1.2 (R Core Team, 2014).

ii. Power calculations performed with G*Power software, version 3.1.7 (Faul et al., 2007).

\begin{tabular}{lllll}
$\mathbf{F}(\mathbf{D f n}, \mathbf{D f d})$ & ${\text { Partial } \eta^{2}}$ & Original effect size $\boldsymbol{f}$ & $\begin{array}{l}\text { Replication total } \\
\text { sample size }\end{array}$ & $\begin{array}{l}\text { Detectable } \\
\text { effect size } \boldsymbol{f}\end{array}$ \\
\hline $\mathrm{F}(24,39)=0.8678$ (interaction) & 0.348120 & 0.7307699 & $169^{\star}$ & $0.3895070 \dagger$ \\
\hline $\mathrm{F}(2,39)=0.8075$ (treatments) & 0.039766 & 0.2035014 & $169^{\star}$ & $0.2415459 \dagger$ \\
\hline $\begin{array}{l}F(12,39)=187.6811 \text { (hematology } \\
\text { parameters) }\end{array}$ & 0.982978 & 7.599178 & $169^{\star}$ & $0.3331365 \ddagger$
\end{tabular}

parameters)

*The replication sample size includes 13 parameters from 3 untreated, 5 IgG-treated, and 5 CD47-treated mice.

†The original data did not detect a statistically significant interaction or treatment main effect, making these the detectable effect size with $80.0 \%$ power.

‡The original data reported a statistically significant effect for the hematology parameters, which the replication is powered to $99.9 \%$ to detect. This is the detectable effect size with $80 \%$ power.

\section{Test family}

A. ANOVA, Fixed effects, omnibus, one-way, Bonferroni's correction alpha error of 0.05/13= 0.00385 .

i. Power calculations performed with G*Power software, version 3.1.7 (Faul et al., 2007).

\begin{tabular}{llllll}
$\begin{array}{l}\text { Hematology } \\
\text { parameter }\end{array}$ & $F($ Dfn, Dfd) & Partial $\eta^{2}$ & $\begin{array}{l}\text { Original } \\
\text { effect size } f\end{array}$ & $\begin{array}{l}\text { Replication total } \\
\text { sample size }\end{array}$ & $\begin{array}{l}\text { Detectable } \\
\text { effect size } f\end{array}$ \\
\hline WBC & $F(2,3)=0.4975$ & 0.249071 & 0.57592 & $13^{*}$ & 1.5234072 \\
\hline Lym & $F(2,3)=0.3297$ & 0.180209 & 0.468853 & $13^{*}$ & 1.5234072 \\
\hline Mono & $F(2,3)=0.9781$ & 0.394709 & 0.8075258 & $13^{*}$ & 1.5234072 \\
\hline Gran & $F(2,3)=1.0706$ & 0.416476 & 0.8448228 & $13^{*}$ & 1.5234072 \\
\hline HCT & $F(2,3)=3.7673$ & 0.715222 & 1.584774 & $13^{*}$ & 1.5234072 \\
\hline MCV & $F(2,3)=58.2710$ & 0.974904 & 6.232735 & $13^{*}$ & 1.5234072 \\
\hline RDWa & $F(2,3)=96.1000$ & 0.984631 & 8.004127 & $13^{*}$ & 1.5234072 \\
\hline HGB & $F(2,3)=2.0036$ & 0.571864 & 1.155728 & $13^{*}$ & 1.5234072 \\
\hline MCHC & $F(2,3)=83.1450$ & 0.982279 & 7.445148 & $13^{*}$ & 1.5234072 \\
\hline RBC & $F(2,3)=2.9797$ & 0.665153 & 1.409411 & $13^{\star}$ & 1.5234072 \\
\hline MCH & $F(2,3)=1.3714$ & 0.477612 & 0.956183 & $13^{*}$ & 1.5234072 \\
\hline PLT & $F(2,3)=0.8536$ & 0.362682 & 0.7543709 & $13^{*}$ & 1.5234072 \\
\hline MPV & $F(2,3)=1.9231$ & 0.561798 & 1.132278 & $13^{*}$ & 1.5234072
\end{tabular}

*The replication sample size includes three untreated, five lgG-treated, and five CD47-treated mice.

\section{Acknowledgements}

The Reproducibility Project: Cancer Biology core team would like to thank the original authors, in particular Stephen Willingham and Jens-Peter Volkmer, for generously sharing critical information as well as reagents to ensure the fidelity and quality of this replication attempt, as well as Frank Graham and McMaster University for facilitating the transfer of MT1A2 cells. We thank Courtney Soderberg at the Center for Open Science for assistance with statistical analyses. We would also like to thank the following companies for generously donating reagents to the Reproducibility Project: Cancer Biology; American Type Culture Collection (ATCC), BioLegend, Cell Signaling Technology, Charles River Laboratories, Corning Incorporated, DDC Medical, EMD Millipore, Harlan Laboratories, LI-COR Biosciences, Mirus Bio, Novus Biologicals, Sigma-Aldrich, and System Biosciences (SBI). 


\section{Additional information}

Group author details

Reproducibility Project: Cancer Biology

Elizabeth lorns: Science Exchange, Palo Alto, California; William Gunn: Mendeley, London, United Kingdom; Fraser Tan: Science Exchange, Palo Alto, California; Joelle Lomax: Science Exchange, Palo Alto, California; Timothy Errington: Center for Open Science, Charlottesville, Virginia

Competing interests

DC: This is a Science Exchange Associated lab. RP:CB: EI, FT and JL are employed by and hold shares in Science Exchange Inc. The other authors declare that no competing interests exist.

Funding

\begin{tabular}{ll} 
Funder & Author \\
\hline Laura and John Arnold & Reproducibility Project: \\
Foundation & Cancer Biology
\end{tabular}

The funders had no role in study design, data collection and interpretation, or the decision to submit the work for publication.

Author contributions

DC, NM, EG, Drafting or revising the article; RP:CB, Conception and design, Drafting or revising the article

\section{References}

Chan KS, Espinosa I, Chao M, Wong D, Ailles L, Diehn M, Gill H, Presti J Jr, Chang HY, van de Rijn M, Shortliffe L, Weissman IL. 2009. Identification, molecular characterization, clinical prognosis, and therapeutic targeting of human bladder tumor-initiating cells. Proceedings of the National Academy of Sciences of USA 106: 14016-14021. doi: 10.1073/pnas.0906549106.

Chao MP, Alizadeh AA, Tang C, Jan M, Weissman-Tsukamoto R, Zhao F, Park CY, Weissman IL, Majeti R. 2010 a. Therapeutic antibody targeting of CD47 eliminates human acute lymphoblastic leukemia. Cancer Research 71:1374-1384. doi: 10.1158/0008-5472.CAN-10-2238.

Chao MP, Alizadeh AA, Tang C, Myklebust JH, Varghese B, Gill S, Jan M, Cha AC, Chan CK, Tan BT, Park CY, Zhao F, Kohrt HE, Malumbres R, Briones J, Gascoyne RD, Lossos IS, Levy R, Weissman IL, Majeti R. $2010 b$. Anti-CD47 antibody synergizes with rituximab to promote phagocytosis and eradicate non-Hodgkin lymphoma. Cell 142:699-713. doi: 10.1016/j.cell.2010.07.044.

Demaria S, Volm MD, Shapiro RL, Yee HT, Oratz R, Formenti SC, Muggia F, Symmans WF. 2001. Development of tumor-infiltrating lymphocytes in breast cancer after neoadjuvant paclitaxel chemotherapy. Clinical Cancer Research 7:3025-3030.

Edris B, Weiskopf K, Volkmer AK, Volkmer JP, Willingham SB, Contreras-Trujillo H, Liu J, Majeti R, West RB, Fletcher JA, Beck AH, Weissman IL, van de Rijn M. 2012. Antibody therapy targeting the CD47 protein is effective in a model of aggressive metastatic leiomyosarcoma. Proceedings of the National Academy of Sciences of USA 109:6656-6661. doi: 10.1073/pnas.1121629109.

Faul F, Erdfelder E, Lang AG, Buchner A. 2007. G*Power 3: a flexible statistical power analysis program for the social, behavioral, and biomedical sciences. Behavior Research Methods 39:175-191. doi: 10.3758/BF03193146.

Goto H, Kojima Y, Matsuda K, Kariya R, Taura M, Kuwahara K, Nagai H, Katano H, Okada S. 2014. Efficacy of anti-CD47 antibody-mediated phagocytosis with macrophages against primary effusion lymphoma. European Journal of Cancer 50:1836-1846. doi: 10.1016/j.ejca.2014.03.004.

Jaiswal S, Jamieson CH, Pang WW, Park CY, Chao MP, Majeti R, Traver D, van Rooijen N, Weissman IL. 2009. CD47 is upregulated on circulating hematopoietic stem cells and leukemia cells to avoid phagocytosis. Cell 138:271-285. doi: 10.1016/j.cell.2009.05.046.

Kim D, Wang J, Willingham SB, Martin R, Wernig G, Weissman IL. 2012. Anti-CD47 antibodies promote phagocytosis and inhibit the growth of human myeloma cells. Leukemia 26:2538-2545. doi: 10.1038/leu.2012.141.

Majeti R, Chao MP, Alizadeh AA, Pang WW, Jaiswal S, Gibbs KD Jr, van Rooijen N, Weissman IL. 2009. CD47 is an adverse prognostic factor and therapeutic antibody target on human acute myeloid leukemia stem cells. Cell 138:286-299. doi: 10.1016/j.cell.2009.05.045

Maxhimer JB, Soto-Pantoja DR, Ridnour LA, Shih HB, Degraff WG, Tsokos M, Wink DA, Isenberg JS, Roberts DD. 2009. Radioprotection in normal tissue and delayed tumor growth by blockade of CD47 signaling. Science Translational Medicine 1:3ra7. doi: 10.1126/scitranslmed.3000139.

Murata Y, Kotani T, Ohnishi H, Matozaki T. 2014. The CD47-SIRPalpha signalling system: its physiological roles and therapeutic application. Journal of Biochemistry 155:335-344. doi: 10.1093/jb/mvu017. 
Oldenborg PA. 2013. CD47: A Cell Surface Glycoprotein which Regulates Multiple Functions of Hematopoietic Cells in Health and Disease. ISRN Hematology 2013 614619. doi: 10.1155/2013/614619.

Poon IK, Lucas CD, Rossi AG, Ravichandran KS. 2014. Apoptotic cell clearance: basic biology and therapeutic potential. Nature reviews. Immunology 14:166-180. doi: 10.1038/nri3607.

R Core Team. 2014. R: a language and environment for statistical computing. R Foundation for Statistical Computing, Vienna, Austria. URL: http://www.R-project.org/.

Soto-Pantoja DR, Miller TW, Frazier WA, Roberts DD. 2012. Inhibitory signaling through signal regulatory protein-a is not sufficient to explain the antitumor activities of CD47 antibodies. Proceedings of the National Academy of Sciences of USA 109:E2842. doi: 10.1073/pnas.1205441109.

Willingham SB, Volkmer JP, Gentles AJ, Sahoo D, Dalerba P, Mitra SS, Wang J, Contreras-Trujillo H, Martin R, Cohen JD, Lovelace P, Scheeren FA, Chao MP, Weiskopf K, Tang C, Volkmer AK, Naik TJ, Storm TA, Mosley AR, Edris B, Schmid SM, Sun CK, Chua MS, Murillo O, Rajendran P, Cha AC, Chin RK, Kim D, Adorno M, Raveh T, Tseng D, Jaiswal S, Enger PO, Steinberg GK, Li G, So SK, Majeti R, Harsh GR, van de Rijn M, Teng NN, Sunwoo JB, Alizadeh AA, Clarke MF, Weissman IL. 2012. The CD47-signal regulatory protein alpha (SIRPa) interaction is a therapeutic target for human solid tumors. Proceedings of the National Academy of Sciences of USA 109:6662-6667. doi: 10.1073/pnas.1121623109. 